\title{
The Views of Social Studies Teachers on Distance Education
}

\author{
Zafer ÇAKMAK ${ }^{1}$ \\ Firat University, Elazığ, TURKEY
}

\author{
Turan KAÇAR ${ }^{2}$ \\ TOBB Ferdi Yiğit High School, Diyarbakır, TURKEY
}

${ }^{1}$ Corresponding author: Prof. Dr.; University of Firat, Faculty of Education, Department of Social Studies Education, Elazig, TURKEY. zcakmak [at] firat.edu.tr. ORCID: 0000-0002-0612-814X

${ }^{2}$ Dr.; TOBB Ferdi Yigit High School, Diyarbakir, TURKEY. kacarturan21 [at] gmail.com. ORCID: 0000-0001-8390-7262

\begin{abstract}
The Face-to-face training activities were suspended in Turkey in mid-March 2020 due to the COVID-19 (Corona virus) global pandemic, which is rapidly increasing its impact in the world and Turkey. The aim of this study is to determine the opinions of social studies teachers working in Diyarbakır regarding distance education activities carried out by the Ministry of National Educaion. When the literature is examined, the fact that there are not many studies to determine the views of social studies teachers on distance education shows the need for this study. This study is in the phenomenology model and was conducted as a qualitative research Semi-structured interview technique was used for data collection. The study group of the research consists of 20 social studies teachers working in secondary schools in Diyarbakır in the first semester of the 2020-2021 academic year. In order to conduct this study, necessary permissions were obtained from Firat University Ethics Committee and Diyarbakır National Education Directorate. In this study, 11-item interview questions were used as data collection tools in the interviews with the participants. The semi-structured interview with the participants was carried out with the distance education module (Zoom), and the data were recorded by voice recording. The data collected within the scope of this study were analyzed according to the "descriptive analysis" method. According to the results of this study; In the distance education process, the necessary equipment and internet for students is inadequate. During the distance education process, students have a low level of participation in live lessons
\end{abstract}

\section{Keywords}

Covid-19 Global Epidemic; Distance Education; Social Studies; Social Studies Teachers; Turkey 
Distance education is a very important learning activity that can be carried out in an online or offline form where the learner and the teacher are not in the same environment, and mainly through technological means. This learning activity is an important activity that provides significant savings, especially in terms of time, space and economic. Therefore, it can be said that distance education activities are an indispensable learning method, especially in the Covid-19 global epidemic we are experiencing today. It can be said that distance education activities have become a very important learning method both in our country and in the world due to the Covid-19 global pandemic that started from China in late 2019 and spread all over the world.

Internet-based distance education is one of the educational models carried out in order to provide a better service and to ensure that education is carried out in accordance with the conditions of the age (Odabas, 2003). "Distance education can be expressed as a synchronous or asynchronous training in which the learner and the teacher are located in different places." (Kacan \& Gelen, 2020, p.3). Distance education is a form of education in which the learner and the teacher are in physically different places (Adiyaman, 2002). In addition to these definitions, distance education activities are an educational practice carried out by the student and teacher communicating in different places, at the same or different times (Odabas, 2003).

The purpose of distance education activities; to provide education opportunities for people with technological systems that can adapt to developing technology, be unaffected by time and space and benefit human education by eliminating the time and geographical barriers that cause disruption of education (Ozbay, 2015). In addition, according to Y1lmaz and Guven (2015), experiences related to distance education activities and knowledge of distance education affect perceptions of distance education and perceptions for distance education affect the success of distance education.

According to Ozbay (2015), distance education activities both reduce the cost of education and increase the quality of education. "In distance education, flexibility in time, space and learning speed should be offered to the individual, interaction should be ensured to be two-way and measurable, learning-teaching activities should be prepared and carried out according to the individual's preference." (Demir, 2014, p. 207). Distance education activities can be more useful and effective.

The development of the society in terms of education with information technologies depends on having access to learning materials regardless of time and place (Erguney, 2015). Distance education activities can be carried out with information technologies not only in education but in almost all areas of life today and in the future. Distance education activities, which have become more important with the individualization of education, have shown rapid development and change in recent years, and significant investments have been made in distance education activities in many parts of the world (Kacan \& Gelen, 2020). "Distance education has become an indispensable requirement in terms of the continuous development of technology and its rapid renewal, the fact that the education that individuals face cannot meet the needs of the developing world, and the individuals constantly renew themselves." (Kacan \& Gelen, 2020, p.2). In the face of these essential needs, public institutions and organizations that appeal to a significant part 
of the society in the distance education process should be able to do their thinking tasks properly.

Individuals who cannot obtain face-to-face education can receive distance education via the internet, which is used as an educational tool with the development of technology (Kor, Cataloğlu \& Erbay, 2013). Distance education has become a normal necessity of our lives due to various problems (economic, health, weather events etc.) in our country and in the world. Within the framework of these needs, educational institutions, with the responsibility of responding to the demands of the students, turned to seek different methods in education and training, leading to the development of distance education activities that include a different understanding from the traditional education system (Eygu \& Karaman, 2013). Distance education activities are very important for countries to make their learning activities continuous. In addition, due to the inconvenience of physical and economic conditions of individuals, many countries need to make significant investments in distance education activities.

As can be seen from all these definitions, distance education is in different places; is an important training activity that can be carried out online or offline at the same or different times. Since the beginning of the 20th century, distance education, which has spread all over the world, has passed through various stages in terms of historical development (Coban, 2012). These statements addressing the historical development of distance education activities in Turkey in the light is very important.

The first practices of distance education began in 1974 with the activities of the institution "Higher Education Center by Letter" in order to improve education activities at the associate level for people who did not have higher education opportunities in Turkey (Toker Gokce, 2008; Kor, Cataloglu \& Erbay, 2013). Then it can be said that the first examples of distance education activities in Turkey took place in 1982 with the opening of the open education faculty, which operates under Anadolu University. As a matter of fact, according to Bozkurt (2017); the first applications of distance education activities in Turkey began after 1980 with the establishment of Anadolu University Faculty of Open Education. Because Anadolu University, open education high school and primary school applications affiliated with the Ministry of National Education (MNE) are the most well-known examples of distance education in our country (Eygu \& Karaman, 2013). It is known that applications similar to distance education activities or in-service training activities are carried out in many universities and public institutions and organizations in Turkey later.

Accordingly, it can be said that distance education activities in Turkey are new and have recently increased the development of distance education activities (Coban, 2012). "Since the late 1990s and early 2000s, educational opportunities offered by distance education have increased with developments in the field of information and communication technologies (ICT) and distance education has been part of the mainstream in education in our country with the students reaching millions." (Bozkurt, 2017, p.86). As a matter of fact, "Distance education has brought a new approach to learning and teaching with the opportunities it offers to the individual and has become a widely used method today." (Fidan, 2016, p.537). Distance education is carried out in 26 
public universities and 9 foundation universities in Turkey (Coban, 2012). Associate, undergraduate, masters and certificate programs are carried out with distance education applications in many higher education institutions in Turkey (Ozbay, 2015).

Due to rapidly increase its influence in the world and Turkey Covid-19 global epidemic in Mid-March of 2020 has had to be suspended for the face-to-face training activities. In Turkey, the training activities were interrupted on March 16, 2020 on March 23, 2020 but the activity has begun to distance education through television channels. For all primary, secondary and high school students, the courses and education programs prepared on the TRT Education Information Network (EIN) TV channels were tried to be continued without interruption at all levels. (Osmanoglu, 2020, p.69). At the beginning of the 2020-2021 academic year, only preschool and 1st grades started face-to-face training partially ( 1 or 2 days a week) and in the 8th and 12th grades, educational activities were started in a controlled manner in the context of the Support and Training Course. Then, partial face-to-face training activities were carried out two days a week in a gradual and diluted form (10 lessons per week in elementary schools, 12 in middle schools and 14 hours in high schools). However, due to the Covid-19 global pandemic, which has become widespread again in Turkey and around the world, face-to-face education was suspended again shortly afterwards and distance education activities continued to be carried out at all levels of education. In the process, TRT EIN television channels in Turkey, EIN activities carried out by means of course that perform live on the network has continued to distance education activities.

EIN, in Turkey elementary school, middle school and high school students an important they can remotely carry out training activities at the network. With EIN, students are given the opportunity to complete their shortcomings in the field of education. Teachers have been given the opportunity to send various assignments and studies to their students via EIN.

According to social studies teachers from the middle of the second semester of 20192020 academic year to determine their view of distance education activities carried out by the MNE in Turkey is very important. Therefore, the aim of this study is to determine the opinions of social studies teachers working in Diyarbakir province regarding the distance education activities carried out by the Ministry of National Education in Turkey. When the literature is examined, the lack of studies aimed at determining the views of social studies teachers for distance education clearly shows the need for this study and its contribution to the field of social studies education. This is the main problem of this study is to Covidien-19 global pandemic because the MNE in Turkey 2019-2020 academic year Diyarbakir for distance education activities carried out since the second period who work in the province to identify the views of the social studies teacher.

\section{Methodology}

\section{Research Model}

This study is in phenomenology model and was conducted as a qualitative research and semi-structured interview technique which is suitable for qualitative research was used in data collection. Interview, one of the commonly used data collection techniques 
Çakmak, Z.; Kacar, T. (2021). The views of social studies teachers on distance education...

in the research; It is a purposeful interview in which pre-prepared questions are asked and the other person answers the questions (Kus, 2003).

\section{Study Group}

The study group of this research is 20 social studies teachers working in various secondary schools in Diyarbakir province in the 2020-2021 academic year. The criteria included in the sampling method for the study group of this research are determined by sampling. "In a study of criteria sampling, observation units can be created from individuals, events, objects, or situations with certain qualifications. In this case, the units that meet the criteria specified for the sample are sampled." (Buyukozturk, Cakmak, Akgun, Karadeniz \& Demirel, 2010, p.91). The criterion used in this study is that the participants are social studies teachers. In this respect, participants were determined according to random sampling. In this respect, the researchers obtained the necessary permissions from Firat University Social and Human Research Ethics Committee and Diyarbakır Provincial Directorate of National Education in order to conduct this research.

Some information about the participants in the working group of this research is given in Table 1.

Table 1

Some Information about Participants

\begin{tabular}{|c|c|c|}
\hline Properties & f & $\%$ \\
\hline \multicolumn{3}{|l|}{ Gender of participants } \\
\hline Female & 8 & 40,0 \\
\hline Male & 12 & 60,0 \\
\hline \multicolumn{3}{|c|}{ Teaching experience of the participants } \\
\hline $1-5$ years & 5 & 25,0 \\
\hline $6-10$ years & 8 & 40,0 \\
\hline $11-15$ years & 5 & 25,0 \\
\hline 16 years and above & 2 & 10,0 \\
\hline \multicolumn{3}{|l|}{ Graduation degree of participants } \\
\hline Bachelor degree & 17 & 85,0 \\
\hline Master's degree & 2 & 10,0 \\
\hline PhD degree & 1 & 5,0 \\
\hline \multicolumn{3}{|l|}{ Schools where the participants work } \\
\hline Secondary schools in the city centre & 10 & 50,0 \\
\hline Village secondary school & 8 & 40,0 \\
\hline Private secondary school & 2 & 10,0 \\
\hline Total & 20 & 100.0 \\
\hline
\end{tabular}

As shown in Table 1, $40 \%$ of the participants are women and $60 \%$ are men. $40 \%$ of participants had teaching experience of the participants of 6-10 years, $25 \%$ for 1-5 years, $25 \%$ for $11-15$ years and $10 \%$ for 16 years or more. When the graduation degrees of the participants are examined, $85 \%$ of the participants have bachelor's degrees, $10 \%$ have master's degrees and 5\% have PhDs. 50\% of respondents work in schools in the city center, $40 \%$ in village schools and $10 \%$ in private schools. Participants are numbered from 1 to 20 in the coding stage, and the letter " $\mathrm{K}$ " is added to the beginning of each number-participant 


\section{Data Collection Tool}

In order to ensure that the interview questions made with the participants within the scope of this study are valid and reliable, the researchers firstly conducted a literature review on distance education. Then, study questions (11 questions) were shown to 10 social studies teachers outside the working group to examine the interview questions prepared by the researchers in line with the relevant literature. 11 questions organized after the opinions and suggestions of social studies teachers were presented to two social studies education specialists (a professor and an associate professor). At the end of the opinions and suggestions of field experts, 11-point interview questions were terminated.

In the semi-structured interview; the equipment and internet competence required for participation in distance education, the level of students 'participation in live lessons during the distance education process, the rate of students completing their studies in EIN, the students' following the lessons on TRT EIN TV and the motivation levels of the students in the distance education process were tried to be determined. In addition, the views of participants on the future of distance education were also tried to be determined.

\section{Data Collection and Analysis}

All participants within the scope of this study first filled out the informed consent form. The interview with the participants took approximately 80 minutes. The semi-structured interview with the participants was carried out with a distance education module (ZOOM). Two researchers recorded their interviews with the participants with the ZOOM program. Later, the sound recordings in ZOOM were transferred to forms by two researchers. The content of the opinions transferred to the forms was sent to the participants by e-mail. Participants reviewed and edited their opinions transferred to the forms, and then sent them back to the participants.

In this study, qualitative data collected with the help of open-end questions in semistructured interview form were analyzed according to the 'descriptive analysis' method. According to Y1ldirım and Simsek (2008), the aim of the descriptive analysis is to present the findings obtained to the reader in an edited and interpreted form and the data obtained for this purpose are first described systematically, clearly, and these statements made later are explained and interpreted, and some conclusions are reached by examining the cause and effect relationships.

\section{Findings}

\section{Findings Regarding the Tools and Equipment Required for Students' Participation in Distance Education and Internet Proficiency}

18 out of 20 of the participants found the equipment and internet equipment required for distance education activities of the students inadequate. Participants explain this problem mostly by the inadequate economic situation of the families of the students and the high number of siblings of the students. Below are some participants' opinions on the equipment and internet audibility required during the distance education process.

K10: "In my opinion, the most problematic issue for the students in this process is the insufficient supply of internet and equipment, especially for distance education. Because although I work in a middle school in the city center, most of my students have trouble finding tools, equipment and internets." 
Çakmak, Z.; Kacar, T. (2021). The views of social studies teachers on distance education...

K5: "Since the institution where I work is a private school, I appeal to a group of people who do not have material shortages. As the economic situation of families is generally good, students have sufficient knowledge, tools and equipment and internet."

\section{Findings Regarding the Level of Participation in Live Lessons of Students in the Distance Education Process}

16 out of 20 respondents found the level of participation of students in live lessons inadequate during the distance education process. Participants use this situation on the internet, computer, tablet etc. explained by the inadequacy. Participants also explained this problem with the poor economic situation of the students' families. Below are some participants' views on the level of participation of students in live lessons during the distance education process.

K5: "The participation rate for my live lessons is approximately $15 \%$. Therefore, first of all, I think it is necessary to ensure the technological equipment amenity of the students and to provide free general network to the students and to strengthen the physical infrastructure of distance education applications."

K9: "The participation rate of my students in my live lessons is approximately $20 \%$. I'm sure most of my students want to attend live classes, but they can't attend classes because the tools, equipment and general network required for distance education are not enough. Therefore, students need to be provided with the necessary support."

\section{Findings Regarding Sending Studies to Students from Education Information Network}

All participants stated that they sent the necessary studies to the students through the Education Information Network, but the participants found the rate of completing the necessary studies quite low. Participants think that this problem is mostly related to the insufficient economic level of families. Below are some participants' opinions on sending studies to students from the Education Information Network.

K4: "I send various studies from Education Information Network to my students, but the completion rate of the studies I submit is about $10 \%$. In this regard, I think there is already a problem of tools and internet that is not enough. I also see that children are very reluctant to complete these studies."

K14: "I send students weekly studies, tests and activities through the Education Information Network platform. When I follow the results every week, the rate at which students' complete studies (around $10 \%$ ) is quite low. In my opinion, the inadequate rate at which students complete studies is again due to lack of tools and equipment and lack of internet."

\section{Findings Regarding Students' Level of Following the Lessons on TRT Education Information Network TV}

All participants found the students' level of follow-up on TRT Education Information Network TV to be quite low. Participants explain this situation by the students' finding it boring to watch TV lessons and the unsuitable course hours. Below are some participants' opinions on the level at which students follow courses on TRT Education Information Network TV.

K5: "Since my students do not have many computers, tablets or smart phones, I thought that they generally watch the lessons on TRT Education Information Network TV. However, I can say that most of my students found watching TV lessons quite boring. " 
K16: "The rate of my students following the Education Informatics Network TV (around 10\%) is very low. At the beginning of the epidemic, the participation rate was high, but now students do not want to listen to lectures on television and they get bored quickly. I think the hours of the lessons to be held on television channels should be held at more appropriate times. In addition, the content of the lessons on the Education Information Network TV should be made more fun.

Findings Regarding the Positive and Negative of Distance Education Activities and Live Lessons

All of the participants found the distance education activities and live lessons positively despite the many shortcomings. Participants found distance education activities positive, despite the lack of distance education due to the lack of face-to-face education in the education and training environment for a long time. Below are some of the participants' opinions on the positive and negative aspects of distance education activities and live lessons.

K1: "Low attendance to live lessons or lack of regular attendance are negative aspects. The positive aspect of the live lesson is that students can ask the question they want and solve the desired test."

K10: "It is partially appropriate to reach some of the students with the Education Informatics Network platform and live lessons in distance education activities, but it is very negative that a significant number of students cannot be reached. Because most of my students do not have the necessary tools, equipment and internet at home. Most of the students have television in their homes, but the students do not want to listen to their lessons."

\section{Findings Regarding the Provision of Sufficient and Appropriate Materials in the Distance Education Process}

All of the participants stated that they could provide sufficient and appropriate materials in the distance education process. The participants stated that they could access the information and documents required for their courses on the internet during the distance education process. Some of the participants' views on providing adequate and appropriate materials in the distance education process are given below.

K1: "I don't have a lot of material problems in the distance education process. I can obtain materials from websites on the public network or prepared by the Ministry of National Education."

K10: "During the distance education process, I provide the necessary ready-made materials through the internet and the Education Information Network, but many materials are not up-to-date or appropriate as I want, but I did not prepare materials myself for this."

\section{Findings Regarding the Appropriateness of the Hours and Duration of the TV Courses and Live Lessons on TRT Education Information Network}

12 out of 20 of the participants found the hours and duration of the lectures and live lectures on TRT Education Informatics Network TV appropriate. Most of the participants think that the hours of the live classes are not well planned and scheduled. Participants consider making the necessary arrangements in line with the opinions of both students and teachers in determining the hours of the live lessons to be held. Below are some of 
the participants' opinions regarding the hours and duration of the lessons and live lessons on TRT Education Information Network TV.

$\mathrm{K} 1$ : "There is no specific order in the live class hours, as if the administrators are doing arbitrary practices. I think the three lessons we give for the social studies lesson in the live lesson are sufficient."

K10: "Students often complain about the lecture hours on the Education Informatics Network TV, so they say they do not watch the lectures. In fact, there is no regularity in the hours of the live lessons, sometimes there are lessons in the early hours of the morning, sometimes at noon and sometimes in the evening. That's why I think a good, useful and flexible planning should be done."

\section{Findings Regarding Morale and Motivation Levels of Students in the Distance Education Process}

16 out of 20 of the participants stated that students' morale and motivation levels were low during the distance education process. Participants state that the motivation levels of the students who missed school and abstained from face-to-face education for a long time are low. However, most of the participants think that the live lessons positively affect the motivation of the students, albeit partially. Below are some of the participants' views on the morale and motivation levels of students in the distance education process.

K1: "The morale and motivation of the students are at a very high level during the live lesson. I think students are waiting for the schools to be opened as soon as possible. Because most of my students often express that they miss school very much."

K10: "The morale and motivation of my students who attend the live lesson are generally good during the lesson, but the students are quite bored with this process. The schools not being open significantly lower the morale and motivation of my students."

\section{Findings Regarding Students' Knowledge, Skills, Positive Attitudes and Value Acquisition in the Distance Education Process}

18 out of 20 of the participants stated that the knowledge, skill, positive attitude and value gain of the students in the distance education process was low. The majority of the participants think that gaining knowledge, skills and positive attitudes and values in the distance education process is insufficient. Because a significant portion of the participants think that the distance education process is not enough to motivate students. Some of the participants' views on the knowledge, skills, positive attitude and value acquisition of students in the distance education process are given below.

K10: "In this process, students can partially acquire information, but I think that students' skill, positive attitude and value acquisition are very low. Because it is very difficult to gain skills, positive attitudes and value in distance education activities."

K5: "Students have to be contented with what they have learned about knowledge because after the lesson is not sanctioned by the families, the student does not spend his or her time efficiently outside the lesson. When it comes to skill and value, an activity-based study is very difficult. Since we are not a generation that teaches and listens virtual lessons, we are getting used to this system, and it will be easier for our children to get used to it." 


\section{Findings Regarding the Future of Distance Education}

19 out of 20 of the participants stated that they think the future of distance education is positive. Participants think that due to the COVID 19 global epidemic, distance education activities will be important in the future and will find a place in our lives. Below are some of the participants' views on the future of distance education.

K1: "During the epidemic, many teachers and students' use of technology has increased significantly within a few months. I think the importance of distance education has been understood, so in the future, distance education activities will be carried out more easily."

K10: "I think the future of distance education will be one of the most important activities. I think that distance education activities will not easily come out of our lives, although they decrease significantly after the epidemic. If the necessary infrastructure of distance education is provided, some lessons can be taught with distance education, even if a little. Savings on many issues can be achieved with distance education activities. However, I do not think that distance education activities are very suitable for preschool, primary and secondary school students. Maybe more applicable in high schools and universities."

\section{Findings Regarding the Opinions and Suggestions that Participants Also Want to Express About the Distance Education Process}

Some of the participants' additional opinions and suggestions about the distance education process are given below.

K1: "All of us were caught in a very unprepared way for distance education activities due to a sudden epidemic, but I think that there are still serious problems in distance education (about 10 months), especially in the live course infrastructure. In addition, students and teachers cannot communicate adequately in the distance education process. In addition, some students' interest in distance education is very low."

K10: "In my opinion, the most important problem of distance education activities is the lack of necessary tools, equipment and internet competence in students. In addition, I think that the course contents in distance education activities should be simplified. The important thing in this process should not be to finish the curriculum. In this process, the contents of the course should be simplified and the lessons should be transformed from being boring to more enjoyable. Because students who love distance education can participate more. I think that's why most of the students don't want to be involved in the distance education process."

K5: "I think this process looks like a table with four legs. If there is a problem with the system, parent, student and transmitter (teacher), I think that the table will not be able to stand firm. In order to be more permanent and not to raise an asocial generation, we must create a good expression and an infrastructure that will appeal to all segments by creating a sense of part of our life."

K11: "I think that the Ministry of National Education should definitely provide the necessary equality of opportunity for conducting distance education activities. If the necessary equality of opportunity is not provided in the distance education process, this may have negative consequences for both students, parents and society."

K17: "I think some of the most neglected elements in this process are as follows. In the distance education process, long-term computers, public networks, phones, tablets, etc. its use can negatively affect both children's health (physical, mental, etc.) and their dependence on technological tools. The use of all kinds of long-term technological tools without paying attention to these results may cause very important problems in the future."

K20: "I think the main problem in distance education is the system problem besides the lack of tools. In other words, a physical infrastructure should be provided so that teachers and students will not have any problems in participating in live lessons." 
K18: "I think participation in distance education is very low because we have many students who do not have computers, tablets, phones and public networks. In addition, the number of students living in the same house is also high, so unfortunately, not everyone can benefit from distance education sufficiently. Not everyone can allocate a budget for computers, phones, tablets and public networks. Apart from this, some of our students have negative attitudes towards distance education, so some students do not care about the lessons. In this process, there are also important problems in technological infrastructure. For example, there are too many connection problems and systemic problems. If success is desired, this is not a problem that only teachers and students can solve. I think the parents of the students have a great job in this regard because they should also follow up the student. Otherwise, problems will continue to be experienced in the distance education process. In addition, many students are not interested in distance education activities, creating a separate problem."

\section{Conclusion and Discussion}

The equipment and internet required for students in the distance education process are insufficient. In the distance education process, the level of participation of students in live lessons is low. Teachers send the necessary studies to the students through the Education Informatics Network, but the rate of completing the required studies and following the lessons on TRT Education Informatics Network TV are very low. Participants show a positive approach to distance learning activities and live lectures, although there are many shortcomings. Participants do not have many difficulties in providing adequate and appropriate materials in the distance education process. Live lessons broadcast on TRT Education Information Network TV are partly suitable. During the distance education process, the morale and motivation levels of most of the students and their knowledge, skills, positive attitude and value acquisition are low. Participants generally see the future of distance education positively.

According to the results of this study, the morale and motivation levels of most of the students in the distance education process are low. According to Karaca, Topal and Aldir (2011), it is difficult to keep students' motivation at a high level in the distance education process. Therefore, it can be said that it is a normal result that students' morale and motivation levels are low during this period of the Covid-19 global epidemic. It will not be easy to recover the morale and motivation levels of students who have been absent from face-to-face education since March 16, 2020 and who have been listening and watching negative news about the Covid-19 global epidemic on the news every day. As a matter of fact, according to Bozkurt (2020), during the Covid-19 global epidemic, where learners are far from their physical and social contexts, educational institutions and educators should work on affective areas. In Fidan's (2020) study, classroom teachers positively evaluate the importance of intrinsic motivation in students in the distance education process, while expressing that they cannot motivate students. In the study conducted by İmamoğlu and Siyimer İmamoglu (2020) in the process of Covid-19 and distance education for teachers, teachers who took a stance in favor of the prolongation of distance education, stated that there was a lack of existing infrastructure and students' access to the system during this process, leading to a loss of motivation in students and teachers.

According to Yildirim (2020), students should be allowed to take more roles in their learning in the distance education process, and methods that serve research and project studies that allow students to act interactively and cooperatively with their friends in 
online environments should be applied. In the light of this information, according to Toker Gokce (2008), the role of distance education in affecting social change is accepted all over the world. According to Okan (2020, p. 32), "Making the course contents more efficient, taking into account the needs of the students and providing psychological support to the students" will make the course process more efficient in online courses conducted in the distance education process. Based on this statement, perhaps the morale and motivation levels of the students can be increased in the distance education process.

According to the results of this study, since the equipment and internet required for students in the distance education process are insufficient, the level of participation of students in distance education activities and live lessons is low. The biggest obstacles to the effective and efficient use of the Education Information Network in the distance education process in the study conducted by Turker and Dundar (2020) for high school teachers regarding distance education carried out through the Education Information Network during the Covid-19 global epidemic; infrastructure problems and hardware deficiencies. In the study where Hebebci, Bertiz and Alan (2020) examined the views of students and teachers on distance education, the lack of infrastructure and inadequate internet connection, especially in rural areas, during the Covid-19 global epidemic, limits distance education activities. Korkmaz and Toraman (2020) in his study in Turkey in Covid-19 students have experienced significant global outbreak internet connection problems. According to the results of the study conducted by Doğan and Kocak (2020), students who experienced lack of technological tools and equipment and internet during the distance education process had difficulty in being involved in the process.

According to Karaca, Topal and Aldir (2011), it is very important to manage the infrastructure of distance education activities. According to Bozkurt (2020), investments should be made in technology infrastructure and education technologies in a meaningful way and in line with the needs. Karakaya, Arik, Cimen and Yilmaz (2020) Covid-19 there are certain problems arising from the lack of infrastructure for distance education and information in their study process in Turkey in the global epidemic. Karabudak (2020) in similar direction Covid-19 in global outbreak in Turkey for his work on distance education process for teachers; in this process, classroom teachers experienced a lack of internet and technical knowledge. According to Karaca, Topal and Aldir (2011), the easier access to distance education activities is, the more comfortable it is in education. One of the most important reasons why students do not have sufficient access to distance education activities may be the inadequate equipment and internet required for students.

According to Ciftci and Aydin (2020), the live course application that emerged during the Covid-19 global epidemic in our country seems to be the most important part of the Education Information Network platform. According to the results of this study, the hours and duration of the live lessons broadcast on TRT Education Information Network TV are partially suitable. This problem may have arisen from the fact that teachers and students are also not included in the planning phase of the lessons to be held in the distance education process. According to Karaca, Topal and Aldir (2011), planning the distance education program is very important. According to Bozkurt and Sharma (2020), distance education activities are a complex process that requires careful planning, design 
and determination of goals in order to create an effective learning environment. As a matter of fact, according to Yildirim (2020), in the distance education process carried out with the Covid-19 global epidemic, a confusion occurred in the working hours of teachers and their working hours spread almost throughout the day. According to Yildirim (2020), the majority of teachers do not have enough knowledge, experience and time about distance education in the distance education process after the Covid-19 global epidemic. In addition, it can be said that the distance education activities carried out under these conditions are not completely distance education activities, since in most cases there are deficiencies in infrastructure, equipment, hardware and software.

According to the results of the study conducted by Dogan and Koçak (2020), the distance education process is supported by the vast majority of teachers. This result also significantly coincides with the results of this study. In Karakaya, Arik, Cimen and Yilmaz's (2020) study of distance education in the Covid-19 global pandemic, biology teachers' thoughts on distance education are positive. Similarly, teachers' perceptions of distance education activities are positive in the study in which Hebebci, Bertiz and Alan (2020) examined the views of students and teachers towards distance education. According to the results of this study, teachers generally see the future of distance education as positive.

In line with the results of the study conducted by Dogan and Kocak (2020), the indifference of the students to the system according to the teachers' opinions also decreased the participation. This result partially overlaps with the results of this study. Because, according to the results of this study, some of the teachers stated that students were indifferent to distance education activities. In the study where Hebebci, Bertiz, and Alan (2020) examined the views of students and teachers on distance education, especially teachers with more than ten years of professional seniority and some teachers who did not have distance education experience before, they often think that distance education can never be as effective as face-to-face education. According to Rahman, Karim, and Byramjee (2015), trainers should be very efficient in using technology to effectively deliver distance education and develop materials. According to the results of this study, teachers do not have much trouble in providing sufficient and appropriate material in the distance education process. It can be said that this result is beneficial in the implementation phase of distance education activities. In addition, according to the participants of Akkaş Baysal's (2020) study on the paradigm change in the school concept and the reopening of schools after the Covid-19 epidemic in January 2020, schools should not only be places where face-to-face education is given, but also the center of distance education. Based on this explanation, teachers may have adapted to this process quickly due to the teachers' adoption of the understanding of distance education.

According to the opinions of the teachers in the study conducted by Fidan (2020), negative statements were included due to the connection problems in the distance education process. It can be said that this result significantly overlaps with the results of this study. Because most of the participants stated that they experienced serious systemic problems, especially in live lessons. 
In line with the findings obtained from the results of this study, the following suggestions for the system, administrators, teachers and parents were presented.

- Adequate internet and equipment should be provided to students and teachers in the distance education process.

- Efforts should be made to increase the ratio of students watching the lessons on TRT Education Information Network TV.

- The hours and duration of the lessons broadcast on the TRT Education Information Network TV channel and the live lessons given by the teachers should be improved.

- Necessary measures should be taken to increase the morale and motivation levels of students in the distance education process.

- Necessary measures should be taken to increase students' knowledge, skills, positive attitude and value acquisition in the distance education process.

- Connection problems or systemic problems experienced in the distance education process must be resolved.

- It should be ensured that students and teachers use technology in the distance education process in accordance with both physical and mental health.

- Parents should be more active in monitoring and directing their students' activities in the distance education process.

- Course contents in the distance education process should be simplified and the lessons should be transformed into a more enjoyable one.

\section{References}

Adıyaman, Z. (2002). Uzaktan eğitim yoluyla yabancı dil öğretimi. The Turkish Online Journal of Educational Technology, 1(1), 92-97.

Akkaş Baysal, E. \& Ocak, G. (2020). Covid-19 salgını sonrasında okul kavramındaki paradigma değişimine ve okulların yeniden açılmasına ilişkin öğretmen görüşleri. Türk Eğitim Bilimleri Dergisi, 18(2), 172-201.

Bozkurt, A. (2017). Türkiye'de uzaktan eğitimin dünü, bugünü ve yarını. Açıöğretim Uygulamaları ve Araştırmaları Dergisi, 3(2), 85-124.

Bozkurt, A. (2020). Koronavirüs (Covid-19) pandemi süreci ve pandemi sonrası dünyada eğitime yönelik değerlendirmeler: Yeni normal ve yeni eğitim paradigması. Açı̋öğretim Uygulamaları ve Araştırmaları Dergisi, 6(3), 112-142.

Bozkurt, A. \& Sharma, R. C. (2020). Emergency remote teaching in a time of global crisis due to CoronaVirus pandemic. Asian Journal of Distance Education, 15(1), 1-6. doi: https://doi.org/10.5281/ zenodo.3778083

Büyüköztürk, Ş., Çakmak, E. K., Akgün, Ö. E., Karadeniz, Ş. \& Demirel, F. (2010). Bilimsel araştırma yöntemleri (5. baskı). Ankara: Pegem A Yayınevi.

Çiftçi, B. \& Aydın, A. (2020). Eğitim Bilişim Ağı (EBA) platformu hakkında fen bilimleri öğretmenlerinin görüşleri. Journal of Turkish Chemical Society Section C: Chemistry Education, 5(2), 111-130.

Çoban, S. (2012, November). Uzaktan ve teknoloji destekli eğitimin gelişimi [Öz]. XVII. Türkiye'de İnternet Konferansında sunulan bildiri, Eskişehir, Türkiye

Demir, E. (2014). Uzaktan eğitime genel bir bakış. Dumlupınar Üniversitesi Sosyal Bilimler Dergisi, 39, 203-211. 
Doğan, S. \& Koçak, E. (2020). EBA sistemi bağlamında uzaktan eğitim faaliyetleri üzerine bir inceleme. Journal of Economics and Social Research Ekonomi ve Sosyal Araştırmalar Dergisi, 7(14), 110-124.

Ergüney, M. (2015). Uzaktan eğitimin geleceği: MOOC (Massive Open Online Course). Eğitim ve Öğretim Araştırmaları Dergisi, 4(4), 15-22.

Eygü, H. \& Karaman, S. (2013). Uzaktan eğitim öğrencilerinin memnuniyet algıları üzerine bir araştırma. Sosyal Bilimler, 3(1), 36-59.

Fidan, M. (2016). Uzaktan eğitim öğrencilerinin uzaktan eğitime yönelik tutumları ve epistemolojik inançları. Hacettepe Üniversitesi Eğitim Fakültesi Dergisi, 31(3), 536-550.

Fidan, M. (2020). Covid-19 belirsizliğinde eğitim: İlkokulda zorunlu uzaktan eğitime ilişkin öğretmen görüşleri. Uş̧ak Üniversitesi Eğitim Araştırmaları Dergisi, 6(2), 24- 43.

Hebebci, M. T., Bertiz, Y. \& Alan, S. (2020). Investigation of views of students and teachers on distance education practices during the Coronavirus (Covid-19) Pandemic. International Journal of Technology in Education and Science (IJTES), 4(4), 267-282.

İmamoğlu, H. V. \& Siyimer İmamoğlu, F. (2020). Coronavirüs salgını ve uzaktan eğitim süreci hakkında öğretmen görüşleri: Şehit Bülent Yalçın Spor Lisesi ve Şehit Ertan Yılmaz Güzel Sanatlar Lisesi (Sinop) örneği. Journal of Humanities and Tourism Research, 10(4), 742761.

Kaçan, A. \& Gelen, İ. (2020). Türkiye'deki uzaktan eğitim programlarına bir bakış. Uluslararası Eğitim Bilim ve Teknoloji Dergisi, 6(1), 1-21.

Karabudak, M. G. (2020). Opinions of 1 st grade teachers on distance education adaptation process during the Covid 19 pandemic period. Social Scientific Centered Issues, 2(2), 72-80.

Karaca, O., Topal, M. \& Aldır, Z. (December, 2011). Uzaktan eğitim sorunları [Öz]. International Science and Teknology Coference'de sunulan bildiri, İstanbul, Türkiye.

Karakaya, F., Arık, S., Çimen, O. \& Yılmaz, M. (2020). Investigation of the views of biology teachers on distance education during the Covid-19 pandemic. Journal of Education in Science, Environment and Health (JESEH), 6(4), 246-258. Doi:10.21891/jeseh.792984

Korkmaz, G. \& Toraman, Ç. (2020). Are we ready for the post-Covid-19 educational practice? An investigation into what educators think as to online learning. International Journal of Technology in Education and Science (IJTES), 4(4), 293-309.

Kör, H., Çataloğlu, E. \& Erbay, H. (2013). Uzaktan ve örgün eğitimin öğrenci başarısı üzerine etkisinin araştırılması. Gaziantep University Journal of Social Sciences, 12(2), 267-279.

Kuş, E. (2003). Nicel-nitel araştırma teknikleri: Sosyal bilimlerde araştırma teknikleri nitel mi, nicel mi. Ankara: Anı Yayınc1lı.

Odabaş, H. (2003). İnternet tabanlı uzaktan eğitim ve bilgi ve belge yönetimi bölümleri. Türk Kütüphaneciliği, 17(1), 22-36.

Okan, N. (June, 2020). Pandemi Sürecinde Yapılan Online Derslerin Verimliliğinin İncelenmesi ve Yüz Yüze Yapılan Derslerle Karşılaştırmasının Yapılması. Uluslararası Covid-19 Kongresi: Eğitimde Yeni Normlar, Artvin.

Osmanoğlu, A. E. (2020). Social studies teachers' views on televisional distance education. Journal of Current Researches on Educational Studies, 10(1), 67-88.

Özbay, Ö. (2015). Dünyada ve Türkiye'de uzaktan eğitimin güncel durumu. Uluslararası Eğitim Bilimleri Dergisi, 2(5), 376-394. 
Rahman, M. Karim, R. \& Byramjee, F. (2015). Prospect of distance learning. Journal of International Education Research, 11(3), 173-178.

Toker Gökçe, A. (2008). Küreselleşme sürecinde uzaktan eğitim. Dicle Üniversitesi Ziya Gökalp Eğitim Fakültesi Dergisi, 11, 1-12.

Türker, A. \& Dündar, E. (2020). Covid-19 pandemi sürecinde Eğitim Bilişim Ağı (EBA) üzerinden yürütülen uzaktan eğitimlerle ilgili lise öğretmenlerinin görüşleri. Milli Eğitim Dergisi, 49(1), 323-342.

Yıldırım, K. (2020). İstisnai bir uzaktan eğitim-öğretim deneyiminin öğrettikleri. Eğitim Bilimleri Eleştirel Inceleme Dergisi, 1(1), 7-15.

Yıldırım, Ş. \& Şimşek, H. (2008). Sosyal bilimlerde nitel araştırma yöntemleri (7. baskı). Ankara: Seçkin Yayıncılık.

Yılmaz, G. K. \& Güven, B. (2015). Öğretmen adaylarının uzaktan eğitime yönelik algılarının metaforlar yoluyla belirlenmesi. Turkish Journal of Computer and Mathematics Education, 6(2), 299-322.

\section{Biographical Statements}

Zafer ÇAKMAK was appointed as a professor at Firat University, Faculty of Education, Department of Social Studies Education in 2017. He is still working as a faculty member (Prof. Dr.) at Firat University Faculty of Education. Zafer Çakmak; History of the Republic of Turkey, the Turkish-Greek relations, Cyprus and there are studies related to Social Studies Education.

Turan KAÇAR completed his Ph.D. in social studies education at Firat University in 2020. Turan Kaçar has been working as a social studies teacher since 2005.

\section{Apendix}

\section{Semi-Structured Interview Questions}

The questions in the data collection tool and posed to the participants are given below.

1. What is the level of equipment and internet affability required for your students' participation in distance education?

2. What is the level of participation of students in live lessons during the distance education process and what can be done to increase the level of participation of students in live lessons?

3. Do you send studies to students from Education Information Network, what is the completion rate of these studies and what are your recommendations to increase the work done?

4. What is the level at which your students follow lessons on TRT Education Information Network TV and what can be done to increase participation in Education Information Network TV?

5. What are the positive and negative aspects of your distance education activities and live lessons?

6. Are you able to provide or prepare sufficient and appropriate materials for distance education?

7. Do you think the hours of live lessons are appropriate and do you find live lesson times sufficient?

8. What are the morale and motivation levels of your students in the distance education process?

9. What are your opinions about students' knowledge, skills, attitudes and value gains during the distance education process?

10. What are your views on the future of distance education?

11.Do you have any additional comments or suggestions about the distance education process? 